\title{
The Advocation of Cross-Cultural Dialogue through the Promotion of Moderation via Media and Education
}

\author{
NASHARUDIN MAT ISA ${ }^{1}$
}

\begin{abstract}
History has presented us the pinnacle of human civilisation in the context of coexistence during the 17th century period in Europe itself whereupon the values of mutual tolerance, intellectual acumen, wisdom and moderation reigned supreme par excellence. This beacon of civilisation witnessed the glorious peak of La Convivencia where all were able to live and cooperate successfully towards the advancement of arts, science and humanity. It has also been replicated in parts in other regions of the world hence efforts for cross-cultural dialogue and cooperation is ever pertinent. The rise of extremism and intolerance in the global world today is a challenge to mankind's ability in reclaiming as well as replicating the glory of civilisations past within the present, and beyond. The panacea to the ills of nowadays can be found in moderation and cross-cultural dialogues and initiatives, ably supported and amplified by education and the media.
\end{abstract}

Keywords: cross-cultural dialogue, dialogue, education, media, moderation

The cultural environments of the world is rapidly changing and becoming more and more diversified, due in part to the nature of the globalised world, cross-border migration, claims for and towards distinctive cultural identities, the growing interdependence between the regions within the globe as well the advances of information and media. Cultural diversity, nevertheless, remains an essential condition of the human race and the current realities see to it that individuals and societies are more than ever, living in multicultural and pluralistic normalities hence requiring for the management of one own's cultural affiliations. It needs mentioning that cultural diversity serves as an economic, social and political plus, which needs to be developed and adequately managed. On the other hand, increasing cultural diversity brings about new social and political challenges, which if left unbridled often triggers fear and rejection. Stereotyping, racism, xenophobia, intolerance, discrimination and violence can threaten peace and the very essence of local and national communities.

Be that as it may, the annals of history would undeniably infer that for a period of up to four centuries, there was a time that the followers of Judaism, Christianity and Islam were able to coexist wherein the values of mutual tolerance, intellectual acumen, wisdom and moderation were not only cultivated but reign supreme par excellence. At a time when other civilisations were struggling in the depths of abyss, Andalusian Spain was at the time, the cradle of the human civilisation. The glorious peak that was Andalusia saw to it the Convivencia period wherein Muslims, Christians and Jews were able to live and cooperate successfully towards the advancement of arts, science and humanity among others(UNESCO 2002, Reilly 1995). Similarly, periods of cross-cultural cooperation were visible in Sicily between the various ethnicities and also other periods of cooperation, i.e. olden day Korea and that of China's Ming Dynasty, due to their heightened values and acumen which led to the upholding of tolerance, moderation and

\footnotetext{
${ }^{1}$ Nasharudin Mat Isa, M.A., Chief Executive Officer of Global Movement of Moderates Foundation, 15th Floor, Menara Manulife, No. 6, Jalan Gelenggang, Damansara Heights, 50490 KUALA LUMPUR, Malaysia, email: info@gmomf.org.
} 
peace. Alas, such glorious periods in mankind's civilization started to flounder with the abandoning of the principle of moderation and tolerance in all dimensions of life from social and religious practices to even education. History has gone on accord regarding the rise of intolerance within the people, and consequently, the various factions' venomous vying of power hence deserting the very fabric of what had ensured their successes in the initial phase (Reilly 1995: 231). Thus, in these reversed times proliferated by widespread confusion and extremism whilst seemingly bereft of wisdom, it is only sensible that the world reclaims its central ground based upon moderation, therein replicating in part one of the more storied times of man's civilisation.

The need for bridge-building initiatives and its proper implementation has gathered renewed importance in the pluralistic societies of these globalised times, more so when confronted by the negative elements of "clash of civilisations" and of more recent, the war on terror and extremist ideologies given the unprecedented spread of extremism and violence by individuals and organisations in many parts of the world. The calls for bridge building dialogues, with initial calls for the dialogue of civilisations in the United Nations General Assembly in 1997 by world leaders, in addition to the current Malaysian Prime Minister, Mohd Najib Tun Razak's clarion call via his Global Movement of Moderates at 65 General Assembly in 2010 as well as China's President Xi Jinping's calls for new international relations based on mutual and shared cooperation at the $70^{\text {th }}$ United Nations General Assembly in 2015(Xi Jinping 2015a)in lieu of her One Belt One Road initiatives in readdressing world imbalances. What better way than for these initiatives to take heart and to prosper based upon the glorious cross-cultural cooperation of the past? Al-Andalus provided an outstanding environment for dialogue and contact. That form of coexistence, unparalleled at the time, was destined to have wide-ranging consequences in not only encompassing the Iberian Peninsula and the Maghrib, but stretching to areas of sub-Saharan Africa and Western Europe, whom all benefitted from its enrichment. This cross-cultural boldness led for the transmission of classical Greek culture's foundations and the contributions to philosophy and science of India, Persia and China being disseminated and embraced in Europe (Carrol 2001) thus serving as linkages and bridges between East and West - and between Antiquity and the future Renaissance (UNESCO 2002). To this end, this paper will briefly look into three phases of cross-cultural cooperation and dialogue, between La Convivencia to Malaysia's dialogue for independence and the promise of hope from past lessons in the shape of the Silk Road initiatives.

\section{La Convivencia's Coexistence as Evidence for the Success of Cross-Cultural Dialogue}

The period of Islamic rule in Andalusia serves as a noteworthy model for the capabilities of the spirit of coexistence given that the Muslim conquerors at the time ensured for the preservation of their citizens' cultural and religious complexities via freedom of their faith and places of worship, protection of family and fortune and assuaging to their security as well as general wellbeing(UNESCO 2001). Invariably, this social environment and cohesion between the communities was preserved and respected under the Muslim rule for as long as it did not endangered the safety of the reign and Muslim faith Nevertheless, such a system did prosper to the extent that the Spanish Jewry flourished in Andalusia and in latter days, is also referred by its descendants to be one period of golden age (Reilly 1995). Such an observation is concurred by Fazlur Rahman, who noted that:

Under Muslim leadership, no Jewish holocaust were committed at the hands of Muslims. It was under the Muslim rule that Jewish philosophers such as Ibn Gabirol and Musa ibn Maymun (Moses Maimonides) excelled. In fact, the Jewish experience in Spain, under Muslim rule, was looked upon as a 'Golden Period' as mentioned by $19^{\text {th }}$ century Jewish prime minister of Britain, Benjamin Disraeli.

https://doi.org/10.24035/ijit.10.2016.004 
During this Golden Period, ranging from 1000 C.E. to 1140 C.E., the Jews in Spain lived peacefully under Muslim rule. The Jews recognised, as they were given certain political positions for example Hasdai ibn Shapirut was a counsellor for Caliph 'Abd Rahman III in Cordoba and Ibn Ghanzalah was a minister in Granada. Being able to live in peace and enjoy the spirit of tolerance under Muslim rule, had given the Jews the opportunity to develop their intellectual enterprise, so much so this period was also known as The Golden Age of Hebrew Literature (Fazlur Rahman 1982: 8; Fattah 1997:120).

It is most pertinent to add that such instances of coexistence are congruent to the principles of the maqasid syari ah in Islam itself; a principle which ensures for the protections of one's faith, life, lineage, wealth, and intellect (Jasser Auda 2008: 26).

This period of coexistence, aptly taken from its Spanish derivative La Convivencia, often refers to the interplay of cultural ideas between the three religious groups and the ideas of religious tolerance (Sarah 2013). While some have asserted that in recent times, the term Convivencia itself has somewhat been a politically charged tool used to permeate political discourses in offering mythical vision of tolerance in addition to addressing modern concerns on religious intolerance (Fernandez-Morera 2006: 23-31), it is also noted that the term itself has been "commonly used in the academia since the mid-twentieth century to refer to interaction between different faiths in the Iberian Peninsula" (De Nicola et.al 2015). Admittedly, there were clashes and conflicts and it was not utopian in every sense of the word, but these clashes were mostly politically motivated rather than religious in nature (Fazlur Rahman 1982) as well being of rarer and lesser in degree, as compared to equivalent periods such as John Locke's Christendom (Mudathir 2004 :5; John Locke 1955) and it goes without saying, that such a cultural coexistence of its kind, is still definitive in its own sense and rarely matched in any other time period, especially in the era of the current times, oft-prided in its principles of liberalism, democracy and universalism, to even match it (The UNESCO Courier 1991: 23).

This period of tolerance would reach its zenith during the period of Abdul Rahman's rule wherein not only days with religious connotations were respected, but also in the palaces wherein the great intellectuals of the three religions lived and coexisted with another in a most able and complementary manner. One such prevalent example would be the cooperation between eminent scholars such Ibn al-Kattani, Hasdai ibn Shapirut and Rabi' ibn Zaid, of Muslim, Jewish and Christian backgrounds respectively and much respected in their own fields and religious communities, in assembling and undertaking the task of studying the works of Dioscorides (UNESCO 2002). A resulting consequence of such initiatives was that Arabic language, customs and literature - became the common lingua francabetween the Christians and Jews in which for the latter, it did not pose much of a problem given their respective similarities(Lewis, B 1984)and allowed for the employment of many non-Muslims in various ranks of offices, some of whom achieved the highest rank under the various princes, emirs and caliphs within their respective taifa (UNESCO 2002). Ultimately, it was Muslim Spain's vast intellectual progression, and its resulting prosperity, at a time during which where Christian knowledge was virtually weak (Voughan 2003) was what made them truly distinct in terms of the ability to harness the spirit of tolerance and coexistence. Public literacy was a government priority for the Muslim Spain, and knowledge of Arabic immensely assisted in the cultural, religious and political development between Muslims and non-Muslims alike, hence it was not uncommon for the three main communities to be found to study with one another and the greatest Muslims philosophers and intellectuals had Jewish students, and vice versa (Vaughan 2003) leading to what historians say as: "Under the caliphate, there was great political and religious tolerance. Scholars of various races and religions collaborated closely: good evidence of this is the patronage that Hasdai bestowed upon Muslims and Christians, in addition to his Jewish co-religionists" (UNESCO 2002). 


\section{The Need for Moderation and Initiatives Advocating Civilisational and Cross-Cultural Dialogue}

If earlier it has been mentioned on the periods of La Convivencia, then one would also seek to point to Malaysia's initial experiences of cross-cultural cooperation and dialogue in addition to its role in elements of nation building. While the land of Malaysia (then Malaya) has long been accustomed to cross-cultural experiences due in part to the halcyon days of the Malacca empire and the Straits of Malacca being one of the fundamental naval passing lane for trades, the process and aftermath of Independence from the British represented a much more different challenge. For a most novel nation, it had to deal and negotiated with a most multicultural environment due to British rule. What would transpire would be that the spirit tolerance, moderation and a sense of communal solidarity to be at the vanguard of a new nation. The spirit of cooperation so as to foster a sense of security for all in terms of the public, guided by national leadership and win-win policies that cared and concerned of all its people, ensuring that none are left too far behind. As the father of Malaysian independence, the late Tunku would remark all and sundry, "we must all remember that we are Malaysians.This is the bond that unites us. Let us always remember that unity is our fundamental strength as a people and as a nation." Such declarations, however encouraging, were necessary from the leaders then, since peace could never be attained from one party or race alone, but rather reciprocated by the other parties to the power play. In this regard, in the context of current realities, world leaders have a big role to play and the powers that can be brought against such intolerance is tremendous. It is time that those powers be wielded intelligently and what better way than to ensure for a proper alignment and prosperity of current initiatives with much intercivilisational prospects?

As part of Malaysia's efforts to provide a counter-narrative to challenge the soft power of the extremists in the wider context let alone national spheres, the Malaysian Prime Minister, Mohd Najib Tun Razak, had first mooted the idea of a Global Movement of Moderates (GMM) at a United Nations General Assembly in 2010 prior to a series of discussions and presentations before the formation of such a foundation came to be lauded and accepted by most nations. The basic conception was towards providing a platform for the silent majority to counter extremism in all its forms, as per the words of the Prime Minister, "the real divide is not between Muslims and non-Muslims or between the developed and developing worlds. It is between moderates and extremists"(Najib 2012:7). From therein, the Global Movement of Moderates Foundation (GMMF) would later be launched in 2012, essentially as an approach to combat extremism in all its form, in addition to bringing a new approach in international relations and foreign policy, with its main goal being the application of perspectives and frameworks of moderation as one initiative towards realising world peace and harmony.Central to the initiative is the value of moderation as an approach and a guide for action which strongly emphasises tolerance, understanding, dialogue, mutual respect and inclusiveness. With these key values and objectives, moderation is undoubtedly an important tool and approach to bridge differences and resolve disputes. Malaysia's call for moderation is further epitomised by her role in the initial Bangsamoro 2013 Accord between the Philippine Government and the Moro Islamic Liberation Front, -On Oct 15, 2013, Malaysia help oversaw the signing of the peace agreement between the Philippine Government and the Moro Islamic Liberation Front- which represents a start and an indication on the role moderation can play in areas of conflict resolutions especially since as of 2015, the Global Movement of Moderates has also become an ASEAN initiative (Langkawi Declaration On Global Movement of Moderates 2015). From the perspective of Malaysia, the parallels with moderation is visible through her multi-ethnic society as well as in her constitution, which solidifies Islam as the religion of the state but that all others are free to practice their beliefs in harmony, whilst preserving the sanctity of Islam. In a country consisting a number of Hindus, Christians and Buddhists, racial and religious tensions have been few and far between throughout the years - discounting the recent slight rise in tensions which may

https://doi.org/10.24035/ijit.10.2016.004 
mostly be attributed towards political manipulations - as visible by the tolerance shown in accepting the various holiday rituals and rites of each community. This is an area that Malaysia can promote and share its experiences and best practices. Contrary to the sectarian violence in Myanmar and now spreading to Sri Lanka and India, Malaysia's Buddhist-Hindu-Muslim relations have relatively been respectable and cordial. It is unfortunate that the Sri Lankan Buddhist-Muslim conflict has taken a turn mirroring that of Myanmar's situation. The BuddhistMuslim conflict in the nation concerns not only on holy sites but also ritual slaughters during Eid and even the adornment of the niqab, with even moderate Buddhists having been targeted by the more hard-line Buddhists. This is where the concept of moderation, as espoused by ASEAN, can play a part in any mediatory processes. Ultimately, at a global level, the Global Movement of Moderates seeks to revitalise and organise a series of strategic partnerships so as to strengthen its engagement in a number of events that focuses on finding as well as tackling the root causes of the discord, and also connecting and building the capacity of non-traditional actors and credible voices that can help to provide alternative and counter narratives that would help in the efforts to tackle and thwart any potential growing influence and intensity of propaganda by violent extremist groups in addition to the lingering aftermaths, exacerbated by Islamophobia, in associating the religion with barbarity and terrorism. To that extent, the pertinent question remains, as to how the globalised world can move from such the nadir of intolerance in the current to a desirable track of building the foundations for a just and peaceful coexistence, and strengthening of political, academic, scientific and cultural cooperation between not only the West and the Muslim, but civilisations all over.

If Malaysia's calls for moderation resemble a philosophical platform or approaches amongst nations and civilisations for tolerance and the spirit of dialogue, then modern day China's recent One Belt One Road initiative serves as a key opportunity to combine and present a shared vision as well as application of kindred spirit and economic prosperity to the world. China's One Belt One Road should not be seen merely as a planning of building the Silk Road Economic Belt and the 21st-Century Maritime Silk Road but also the nurturing the spectre of hope, of a strategic initiative which transcends time and space, bridging the inspiration from historical past to the promise of the future. It is essentially a call to connect the various cultures of the world, endowing the Silk Road with a fresh meaning in the new era, and of a historical mission, as per the words of President Xi Jinping (2015b)himself that the One Belt One Road serves to "promote inter-civilization exchanges to build bridges of friendship for our people, drive human development and safeguard peace of the world.It has already been noted that the La Convivencia offers vivid images of coexistence and tolerance, and similar images can also be equated to the old Silk Roads. Historical anecdotes vividly tells of camel envoys, diplomatic missions, merchants, scholars and even the odd tourist navigating with tact and confidence between the various cultures and ethnicities; thus charting new bonds of kinship that continues to be praised and reminisce throughout the centuries (Winter's 2016). If the Silk Road of yesteryears were an ancient trading route covering not only trade and business, but as well as cultural exchanges and diplomatic cooperation running through East and West, and connecting Asia and Europe, then China's proposal of a $21^{\text {st }}$ century version of the Silk Road is explicitly aimed towards not only in the name of revitalisation. Ever more so, it also serves as a proactive effort in developing economic and social partnerships with nations situated along the routes, encompassing Africa, Europe, and Asia.

The One Belt One Road very much fits the common needs of the various nations along the Belt and Road, as well as offering each nation new opportunities of mutual development and financial interchanges. What this ultimately represents is a massive, global initiative that seeks to garner winnable results for all 'member nations' via cross border cooperation. Nonetheless, it must be admitted that the challenges are present given that it covers a vast territory, with each country posing its own set of political systems, laws and regulations as well as ethnic social customs. What is most imperative for the One Belt One Road Initiative is in managing the flow of

https://doi.org/10.24035/ijit.10.2016.004 
information in a convenient and facilitative manner as well as ensuring successful policy, trade and financial integration so as to bring about fruitful people-to-people relations. And herein lay both our promise and our dilemma, towards a fuller and much more correct narrative of the diplomacies between the civilisations of the world.

\section{Role of Education and Media as a Way Forward towards Civilisational Dialogue and Diplomacy}

It has been made mentioned that one factor of much success towards the existence of $L a$ Convivencia was that of public literacy and, as has been numerously advocated by other eminent scholars such as M. Kamal Hassan, education remains a much vital tool towards re-engaging with the current dilemmas of today (Hassan 2011). The multiple threats of extremism at regional and international levels tell us the need to readdress the negative and extremist perceptions that in turn only festers religious and racial discrimination or worse, hatred, such as Islamophobia. The way forward in defeating violent extremism is only through education and cultivation of intellectual discourses. The promotion on the role of education is seen as a key initiative in the building resilience against violent extremism, and work towards the empowerment of youth, women and families to intensify alternative messages that erode the legitimacy of the narratives of violent extremism. Education not only serves as a strong tool towards bridging knowledge gaps (Pearson \& Rochester 1992: 12) between other cultures, but can also be a much effective tool in countering the lure towards extremist tendencies for it is innately evident that intolerance in some ways correlate with ignorance. Moonis Ahmar's observations on the rise of intolerance and extremism in Pakistan are insightful, given that he lists down the following factors as reasons for 'the permeation of extremism in Pakistani society' (Ahmar 2011: 44-63):

1. Use of religion for political purposes

2. Preaching of intolerance and hate from mosques and religious schools

3. Social backwardness and frustration

4. Illiteracy and ignorance

5. Under-development and poverty

6. Absence of rule of law

7. Absence of reasoning and rational approach

8. Unemployment and frustration among the youth

9. Lack of viable democratic culture

10. State's failure to curb extremist and militant groups.

11. Proliferation of drugs and weapons.

12. Lack of tolerance and moderation.

In so far as how the period of La Convivencia had conceived elements of coexistence by synchronisations of political leadership, religious leaders and the community, then so must the current realities also strive for a cohesion between political will and leaders of the current to engage with religious leaders and key members of the community, the media being one example of the latter. Thus, the emphasis on education - in addressing aspects illiteracy, ignorance as well as social backwardness and frustration - must also be ably supported and amplified by the media. The media, which also functions as a form of education in the sense that it dispenses information and opinions, has also been increasingly dominated by corporate interests, through programs promoting the values of a consumer-driven culture (Bagdikian 2000). A large percentage of the news carried in the mainstream media is in fact produced by public relations firms in the form of press releases and video news releases. The information provided by public relations agencies is highly selective with vested interest at times. It highlights information 
which supports the interests of their corporate clients while suppressing information which is not in their interests (Nasharuddin 2016).

For example, in January 2016, in the context of ISIS extremism-Islamophobia narratives, a much noteworthy declaration, namely the Marrakesh Declaration was announced at a Muslim conference attended by esteemed muftis and scholars, ministers of religion in the various Islamic nations including representations by pastors and scholars of other religions. This Declaration, similar to that of A Common Word and a Letter to al-Baghdadi, is a notable example which must be highlighted by the media given its attention and engagement to the rights of minorities, as well as advocating for coexistence - in comparison to the media prominence provided to Islamophobia and extremist threats (Manning 2006). The necessity for policies, engagement and empowering of communities is essential towards prospering civilisational cooperation and dialogue, given, as mentioned previously, that it served as one key element of La Convivencia, whereby under the leadership of Abd Rahman III and his vizer, Hasdai Ibn Shaprut, both had calculatedly fostered policies of reconciliation between the various ethnicities, as well as engaging and empowering them through authoritative positions and rotation of bureaucratic posts (Sarah 2013). Nonetheless, it must be cautioned that there needs a delicate balance between these policies of education and media, since on occasions, propaganda has been known to be equated to education, and this is a gross oversimplification of perspectives. Propaganda uses a set of prefabricated arguments and symbols designed to control the thinking, emotions, and actions of individuals; whereas education aims to present 'all' sides of an issue and lets the individual decide who is right or wrong and what is good or bad (Toma \& Gorman 1991: 93) A study conducted by the Indian-based think-tank Strategic Foresight Group, has indicated that violent extremism stems from a collation of deficits, chief amongst it being deficits in dignity, development as well as governance - and that vested interests groups, organised or otherwise, will invariably manipulate religious undertones in their recruitment of the disillusioned or worse, the vulnerable youths (Strategic Foresight Group's 2007) -additionally, Australian Radicalisation Awareness Kit (2015) gives indications in finding that a common determinant across all types of violent extremism is intolerance and hatred for other points of view.

To conclude, there is an African saying that indicates if one wishes to go fast, then go alone, but if one wants to go far, then one has to go together. The period objectively chosen, the La Convivencia, has more appropriately provided much credible evidence on such a need for closer cooperation, since the balances of society - in Muslim and Christian Iberia - had shifted immensely by the mid- $12^{\text {th }}$ century, in the sense that the two societies were radically diverging apart from one another in differing fashions and directions and at increasing speed, be it in their external relations, internal organisations and address of current then-realitiesm (Reilly 1995: 231). Thus, while the dangers of extremism and terrorism - be it by factions of ISIS, Boko Haram or even the radical Buddhist elements in Myanmar - are a scourge to the global world, it also represents an ample and sui generis of an opportunity, towards further civilisational cooperation and initiatives. The advocating for such co-existential initiatives would indeed require political sinew, not only from the political and religious leaders, but also members of the media and the relevant civil society organisations. To this end, we call for renewed vigour and hope for closer cooperation between the various peace-seeking organisations of the world, to join together with that of ourselves, to truly form a global movement of moderates in not only towards ending the rise of extremism but forming acts of bridge-building initiatives for the betterment of all and for none a nation to be left behind, in accordance to the values of prosper thy neighbour, rather than the creed of beggar thy neighbour. 


\section{References}

Ahmar, M. 2011. The challenge of extremism in Pakistan: Are there lessons to be learnt from the experience of Singapore. IPRI Journal. 11(2): 44-63.

Bagdikian, B. 2000. The Media Monopoly. Boston: Beacon Press.

Carroll, J. 2001. Constantine's Sword: The Church and the Jews. Boston: Houghton Mifflin.

Fazlur Rahman. 1982. Islam's Attitude towards Judaism. The Muslim World. January. 72(1): 1-13.

Fernandez-Morera, D. 2006. The Myth of the Andalusian Paradise. The Intercollegiate Review. 41(2): 23-31.

De Nicola, B., Yildiz, S.N., \& Peacock, A. C. S. (eds.). 2015. Islam and Christianity in Medieval Anatolia. Surrey: Ashgate Publishing.

Fattah, Irfan Abd-al Hamid. 1997. Al-Yahudiyyah: 'Ard Tarikha'. Oman: Dar Ammar.

Hassan, M. K. 2011. Voice of Islamic Moderation from the Malay World. Malaysia: EMIR

Jasser Auda. 2008. Maqasid al-Shariah, A Beginner's Guide. Occasional Paper Series. London: International Institute of Islamic Thought.

Langkawi Declaration on The Global Movement on Moderate. 2015. http://www.asean.org/ langkawi-declaration-on-the-global-movement-of-moderates/ [27 October 2016].

Locke, J. 1955. A Letter Concerning Toleration. New York: Bob Merill.

Lewis, B. 1984. The Jews of Islam. Princeton, NJ: Princeton University Press.

Mudathir Abd. Rahim. 2004. Human Rights and the World's Major Religions: The Islamic Tradition. London: Praegers Publication

Manning, P. C. 2006. Us and Them: A Journalist's Investigation of Media, Muslims and the Middle East. London: Random House.

Najib Tun Hj Abd Razak. 2012. The Global Movement of Moderates. Kuala Lumpur: GMMF.

Nasharudin Mat Isa. 2016.Pivotal role of education and media. http://www.nst.com.my/news/2016/ 04/139468/pivotal-role-education-and-media [26 October 2016].

Pearson, F. S., \& Rochester, J. M. 1992. International Relations: The Global Condition in the Late Twentieth Century. n.l. McGraw-Hill Humanities Social.

Reilly, B. F. 1995. The Contest of Christian and Muslim Spain: 1031-1157. London: Blackwell.

Sarah-Mae Thomas'. 2013. The Convivencia in Islamic Spain. Fountain Magazine July http://www.fountainmagazine.com/Issue/detail/the-convivencia-july-2013[27 October 2016].

Strategic Foresight Group's Report. 2007. An Inclusive World: In which the West, Islam and the Rest have a stake'. http://www.strategicforesight.com/conference_pdf/12578AnInclusive World.pdf [27 Oktober 2016].

The UNESCO Courier. 1991. Between Antiquity and Renaissance. December 1991 Edition, http://unesdoc.unesco.org/images/0009/000903/090316eo.pdf [27 October 2016].

Toma, P. A. \& Gorman, R. F. 1991. International Relations: Understanding Global Issues. n.l. Thomson Brooks/Cole.

UNESCO. 2006. The Routes of Al-Andalus: Spiritual convergence and Intercultural Dialogue. http://unesdoc.unesco.org/images/0011/001144/114426eo.pdf. [27 October 2016].

Vaughan, L. M. 2003. Convivencia: Christians, Jews, and Muslims in Medieval Spain. University of Tennessee, Knoxville: University of Tennessee Honors Thesis Projects.

Winter's, T . 2016 . One Belt, One Road, One Heritage: Cultural Diplomacy and the Silk Road's The Diplomat. http://thediplomat.com/2016/03/one-belt-one-road-one-heritage-culturaldiplomacy-and-the-silk-road/ [27 October 2016].

Xi Jinping. H. E 2015 a. Towards a Community of Common Destiny and A New Future for Asia. Keynote speech by President of the People's Republic of China At the Boao Forum for

https://doi.org/10.24035/ijit.10.2016.004 
Asia Annual Conference 2015. http://news.xinhuanet.com/english/2015-03/29/c_ 134106145.htm [27 October 2016].

Xi Jinping, H. E. 2015b. Working Together to Forge a New Partnership of Win-win Cooperation and Create a Community of Shared Future for Mankind. Statement President of the People's Republic of ChinaAt the General Debate of the 70th Session of the UN General Assembly. http://qz.com/512886/read-the-full-text-of-xi-jinpings-first-un-address/ [28 September 2015]. 